Research Article

\title{
Homocysteine Levels in Patients with Human Immunodeficiency Virus and Acquired Immunodeficiency Syndrome in Ibadan
}

\author{
Tolulase Olutogun, Foluke Fasola, Kehinde Olufemi-Aworinde, Yetunde Aken'ova \\ Department of Haematology and Blood Transfusion Bowen University, iwo. Osun state
}

\begin{abstract}
Introduction: Homocysteine is produced from the conversion of methionine to cysteine. Conditions resulting in hyper homocysteinemia leads to an increased risk of both arterial and venous thromboembolisms by about 2 fold. $20 \%$ of HIV infected patients with objective evidence of venous thromboembolism are found to be thrombophilic with higher homocysteine levels. We enquired into homocysteine levels prior to the development of a clinical evidence of a venous thrombus in both HAART naïve and those on HAART of HIV /AIDS population. We evaluated the association between homocysteine, CD4 lymphocyte count and ART use in order to identify possible risk factors for hyper homocysteinemia in HIV population.

Method: Employing a cross sectional design; we compared mean plasma levels of homocysteine, full blood count parameters and CD4+ lymphocytes counts in HIV positive patients and HIV negative controls. One hundred and twenty patients with HIV infection attending the APIN clinic at the University College Hospital Ibadan and St Mary's Catholic Hospital Eleta Ibadan and one hundred and twenty-six HIV negative healthy controls were compared in the study.
\end{abstract}

Results: Fifty-nine point one percent of the HIV positive patient had hyperhomocysteinemia i.e. homocysteine levels of $>18 \mu \mathrm{mol} / \mathrm{l}$. The mean plasma homocysteine levels were significantly higher at $24.4 \mu \mathrm{mol} / 1(\mathrm{SD}=13.8)(\mathrm{CI}-2$ to $-8 ; \mathrm{p}=0.002)$ in the HIV positive group compared with $19.5 \mu \mathrm{mol} / \mathrm{L}$ $(\mathrm{SD}=10.6)$ in the control group. The use of Anti-retroviral drugs was not associated with higher homocysteine level in the seropositive group and neither were factors like age, gender or the use of combined oral contraceptive pills. There was no correlation between CD4 cell count and homocysteine levels $(\mathrm{r}=-0.01 ; \mathrm{p}=0.9)$.

Conclusion: Homocysteine levels are elevated in HIV positive patients and hyperhomocysteinemia was found in a significant number of HIV positive patients. None of the patients investigated had features of thromboembolism or outright deep venous thrombosis. Neither CD4 cell counts nor traditional risk factors were associated with the higher homocysteine levels.

\section{Background:}

McCully observed arterial lesions in children with inborn errors of methionine metabolism and homocysteinemia. He proposes a causal relationship between homocysteine and vascular disease. (1) Homocysteine (HCY) is produced from methionine which when converted to Sadenosylmethionine (AdoMet) acts as a universal methyl donor. During methylation reactions, AdoMet is converted to $\mathrm{S}$ adenosylhomocysteine (AdoHcy), which is hydrolyzed to adenosine and homocysteine (Hcy) (2). The Hcy formed is reconverted back to methionine or into cysteine in trans sulfuration and remethylation reactions or alternatively metabolized to the cyclic thioester Hcy-thiolactone (3). The Hcy-thiolactone pathway becomes predominant when remethylation or trans sulfuration reactions are disturbed by genetic alterations of enzymes such as cystathionine $\beta$ synthase, methionine synthase, or methylenetetrahydrofolate reductase or by inadequate supply of folate, vitamin B-12, or vitamin B-6. The HCY-thiolactone forms amide bonds with $\varepsilon$-amino groups of protein lysine 
residues. (4). It is the high chemical reactivity of homocysteine-thiolactone that induces endothelial dysfunction. $(5,6)$ It reacts with plasma coagulation proteins and alter their function in vivo, modifying factor $\mathrm{V}$ and inhibiting activated protein $\mathrm{C}$ cleavage $(7,8)$ The sulfhydryl group of the homocysteine thiolactone further mediates disulphide bond formation between fibrinogen and albumin. This cross linking alters polymerization of fibrin strands essential in the formation of stable fibrin clots. (9-11) Hyperhomocysteinemia is relatively common in HIV /AIDS patients and it has been found to directly increase venous thrombosis in HIV /AIDS. Hyperhomocysteinemia is an independent risk factor for both venous and arterial thrombosis in patients between the ages of 20 and 70 years. It is also an independent risk factor for cardiovascular disease $(12,13)$. Patients who were commenced on HAART especially those on protease inhibitors have been found with a higher proportion of hyperhomocysteinemia compared with the HAART naïve. Advancing age is also associated with rising plasma homocysteine levels. With this background information, we set out to investigate the homocysteine levels amongst our HIV positive cohort and to discover if any an association between homocysteine levels, use of HAART and traditional risk factors of hyperhomocysteinemia such as age, gender and smoking history in our HIV group.

\section{Materials and Methods}

Study setting and study population: One hundred and twenty diagnosed HIV positive patients were recruited and selected consecutively into the study from the AIDS Prevention Initiative Nigeria (APIN) Clinic at the University College Hospital, Ibadan, Nigeria and St Mary's Catholic Hospital Eleta, Ibadan, Nigeria. Asymptomatic patients with a confirmed diagnosis of HIV infection were included in the study group. Pregnant female and patients with current clinical evidence and or Doppler ultrasound diagnosis- at any time- of deep venous thrombosis were excluded from the study. Control samples were obtained from 126 healthy adult HIV-negative blood donors (both replacement and volunteer) at the blood bank of the University College Hospital, Ibadan. They were recruited by consecutive sampling method.
Study design: The study was cross sectional in design and the subjects were recruited consecutively.

Sample size estimation

The sample size estimation by the formula

$$
\begin{aligned}
& \mathbf{N}^{87}=\frac{2(Z \alpha+Z \beta)^{2} \sigma^{2}}{\left(\mu_{1}-\mu_{2}\right)^{2}} \\
& \mathrm{~N}=\frac{2(1.96+0.84)^{2} 1.7^{2}}{(0.72)} \\
& =92.8
\end{aligned}
$$

therefore

Where

$\mathrm{Z} \alpha=1.96$ (standard normal deviate corresponding to $5 \%$ level of significance)

$\mathrm{Z} \beta=0.84$ (standard normal deviate corresponding to $80 \%$ power)

$\sigma=$ standard deviation of

Homocysteine $=1.7 \mu \mathrm{mol} / 1$ (14)

$\mu_{1}-\mu_{2}=$ (minimum difference in mean to be detected)

Conservatively, one hundred and twenty subjects were recruited for the study.

Sample collection and analysis: Ten milliliters of venous blood was collected, using standard phlebotomy techniques, from each subject and control. Five milliliters was transferred to a dipotassium EDTA bottle and was used for both full blood count and CD4+ lymphocytes count. Both tests were performed within 2 hours of sample collection. The remaining five milliliters of blood was transferred to a third bottle containing dipotassium EDTA. The sample was centrifuged and the plasma obtained kept at $-20^{\circ} \mathrm{C}$ until analysis. The peripheral full blood count obtained from the anticoagulated samples of patients were determined using Cell-Dyne 1200 Haematology Analyzer (Abbott Diagnostics, North Chicago, IL, USA). The CD4+ T cell lymphocyte count was determined by immunofluorescence using the Cyflow cytometer analyzer $\left(\right.$ Partec $^{\odot}$, Germany). The plasma homocysteine level was determined by a sandwich enzyme linked immunosorbent assay (ELIZA) method using EIA HOMOCYSTEINE FHCY100/FHCY200 (Axis -Shield Diagnostics Ltd, the Technology Park Dundee, United Kingdom). It was read by the Multiskan Ex microplate reader from Labsystems. 
Statistical analysis: Student t- test was used to compare the mean of plasma homocysteine levels between the two groups. Correlation testing was carried out using the Pearson's correlation test on plasma homocysteine levels and full blood count parameters. Hyperhomocysteinemia is defined as plasma homocysteine levels greater than $18 \mu \mathrm{mo} / \mathrm{L}$. ANOVA was used to determine the association between age, use of hormone contraceptive, cigarette smoking, duration of illness and homocysteine levels in the HIV positive group.

\section{Results}

A total of two hundred and forty-six participants were studied consisting of one hundred and twenty HIV positive subjects and one hundred and twenty-six healthy controls. Out of a total of 120 adult HIV positive individuals (study group), $55.8 \%$ were males while $44.2 \%$ were females. Females' age range between 25 and 65 years and males range between 22 and 65 years. The mean age was $32 \pm 7$ years. Out of a total of 126 adult HIV negative blood donors (control group), $39.7 \%$ were females and $60.3 \%$ were males. Mean age was $37 \pm 9$ years. The average years of living with HIV/AIDS among the study group was 4 years (range 6 months-7 years). Sixty-two of the one hundred and twenty participants in the study group were on HAART, 40 of whom were on NNRTI and the remaining twenty-two on Protease inhibitors. All of the participants had HIV 1. Presence of risk factors for hyper homocysteinemia differed in both groups of participants for example, the number of people that smoke cigarettes are higher in the HIV seronegative group but the use of Oral contraceptives was higher in the HIV positive group (table 1). Hematological parameters also differed significantly in both groups. Table 2 contains the hematological parameters of both groups. The platelet counts and MCV were found to be significantly higher in the HIV positive group compared with the seronegative group ( $p$ $=0.00$ respectively). The haemoglobin concentration and haematocrit were significantly lower ( $\mathrm{p}=0.00$ respectively) in the HIV positive group.

The plasma homocysteine level in HIV positive was $24.4 \mu \mathrm{mol} / \mathrm{L} \quad(13.8)$ and the plasma homocysteine level for HIV negative was
$19.5 \mu \mathrm{mol} / \mathrm{L}$ (10.6) (CI -2 to $-8 \mathrm{p}=0.002)$. The results are presented on table 3 . The frequency and percentage of hyperhomocysteinemia (plasma levels $>18 \mu \mathrm{mol} / \mathrm{L}$ ) in both study and control groups was $61(48 \%)$ and $71(59.2 \%)$ respectively. (table 4) The homocysteine levels were higher in those on HAART compared with HAART naive. (table 5)

There was no association found between traditional risk factors (age, sex, use of hormonal contraceptives, cigarette smoking) and plasma homocysteine levels amongst the HIV positive group. The results were presented in Table 6 . There was no correlation between plasma homocysteine and CD4+ $\mathrm{T}$ cell count $(\mathrm{r}=-0.01$ $\mathrm{p}=0.9$ ). The mean CD4 count of HIV positive patients with hyperhomocysteinemia is 453 cells / $\mu l(\mathrm{SD}=234)$. (table 7) Approval was obtained from the University of Ibadan Research and Ethics Committee as well as the Eleta hospital ethics committee

Table 1: Clinical characteristics of the HIV positive and HIV negative groups

\begin{tabular}{|l|c|c|c|c|}
\hline Variable & $\begin{array}{c}\text { HIV } \\
\text { positive } \\
\text { Count(\%) } \\
\mathbf{N = 1 2 0}\end{array}$ & $\begin{array}{c}\text { HIV } \\
\text { negative } \\
\text { Count } \\
(\mathbf{\%}) \\
\mathbf{N = 1 2 6}\end{array}$ & $\begin{array}{c}\chi^{\mathbf{2}} \\
\text { /fisher's } \\
\text { exact } \\
\text { test }\end{array}$ & $\begin{array}{c}\mathbf{P} \\
\text { value }\end{array}$ \\
\hline $\begin{array}{l}\text { History of use } \\
\text { of hormonal } \\
\text { contraceptive }\end{array}$ & $1(0.8)$ & $0(0)$ & 0.5 & 0.5 \\
\hline $\begin{array}{l}\text { Positive } \\
\text { history of } \\
\text { chronic renal } \\
\text { failure }\end{array}$ & $0(0)$ & $1(0.8)$ & 1.0 & 0.5 \\
\hline $\begin{array}{l}\text { Smoking of } \\
\text { cigarette }\end{array}$ & $3(2.5)$ & $6(4.7)$ & 0.5 & 0.3 \\
\hline
\end{tabular}

Table 2: Blood counts and red cell indices of HIV positive and HIV negative groups

\begin{tabular}{|c|c|c|c|c|}
\hline $\begin{array}{l}\text { Blood } \\
\text { Indices }\end{array}$ & $\begin{array}{l}\text { Study } n= \\
120 \\
\text { mean }( \pm \text { SD }\end{array}$ & $\begin{array}{l}\text { Control n } \\
=126 \\
\text { mean }( \pm \text { SD }\end{array}$ & $\begin{array}{l}\text { T } \\
\text { statistic } \\
\text { S }\end{array}$ & $\begin{array}{l}\mathbf{P} \\
\text { value }\end{array}$ \\
\hline $\begin{array}{l}\text { WBC } \\
\left(\times 10^{9} / \mathrm{L}\right) \\
\end{array}$ & $5.3(2.3)$ & $5.2(1.5)$ & -0.35 & 0.73 \\
\hline $\begin{array}{l}\text { Lymphocyt } \\
\text { e }\left(\times 10^{9} / L\right)\end{array}$ & $2.1(1.0)$ & $2.2(0.7)$ & 0.19 & 0.86 \\
\hline Monocyte & $0.6(0.3)$ & $0.5(0.3)$ & -1.63 & 0.11 \\
\hline
\end{tabular}


Tolulase Olutogun, et./al Homocysteine Levels in Patients with Human Immunodeficiency Virus and Acquired Immunodeficiency Syndrome in Ibadan

\begin{tabular}{|l|l|l|l|l|}
\hline$(\times \mathbf{1 0} / \mathbf{L})$ & & & & \\
\hline $\begin{array}{l}\text { Neutrophil } \\
(\times \mathbf{1 0} / \mathbf{L})\end{array}$ & $2.5(1.9)$ & $2.5(1.0)$ & -0.24 & 0.81 \\
\hline & & & & \\
\hline $\mathbf{H g b}(\mathbf{g} / \mathbf{L})$ & $114.4(18.2$ & $123.4(16.1$ & 4.11 & $\begin{array}{l}0.00 \\
*\end{array}$ \\
\hline & & & & \\
\hline PCV (\%) & $35.8(5.5)$ & $38.5(4.5)$ & 4.38 & $\begin{array}{l}0.00 \\
*\end{array}$ \\
\hline MCV (fL) & $96(10.8)$ & $87(6.7)$ & -7.90 & $\begin{array}{l}0.00 \\
*\end{array}$ \\
\hline $\begin{array}{l}\text { MCH (pg.) } \\
\text { MCHC }\end{array}$ & $30.6(4.0)$ & $28.0(3.0)$ & -6.04 & $\begin{array}{l}0.00 \\
*\end{array}$ \\
\hline $\begin{array}{l}\text { (g/L) } \\
\text { Platelet } \\
(\times \mathbf{1 0} / \mathbf{9})\end{array}$ & $232(119)$ & $199(50)$ & -2.84 & $\begin{array}{l}0.00 \\
*\end{array}$ \\
\hline
\end{tabular}

*statistically significant

Table 3: Homocysteine levels $(\mu \mathrm{mol} / \mathrm{L})$ in the HIV positive and HIV negative groups.

\begin{tabular}{|l|l|l|l|l|l|l|}
\hline & $\begin{array}{l}\text { HIV } \\
\text { positive } \\
\text { mean(sd) }\end{array}$ & $\begin{array}{l}\text { HIV } \\
\text { negative } \\
\text { mean(sd) }\end{array}$ & $\begin{array}{l}\text { T } \\
\text { tes } \\
\mathrm{t}\end{array}$ & $\begin{array}{l}\mathrm{C} \\
\mathrm{I}\end{array}$ & $\begin{array}{l}\mathrm{P} \\
\text { val } \\
\text { ue }\end{array}$ \\
\hline & & & & & & \\
\hline $\begin{array}{l}\text { Homocystei } \\
\text { ne }(\boldsymbol{\mu m o l} / \mathbf{L})\end{array}$ & $\begin{array}{l}24.4 \\
(13.8)\end{array}$ & $19.5(10.6)$ & $\begin{array}{l}- \\
2 .\end{array}$ & $\begin{array}{l}- \\
2- \\
8\end{array}$ & $\begin{array}{l}0.0 \\
02\end{array}$ \\
\hline & $\mathrm{n}=120$ & $\mathrm{n}=126$ & & & \\
\hline
\end{tabular}

Table 4: Hyperhomocysteinemia in the HIV positive and HIV negative groups

\begin{tabular}{|l|l|l|l|l|l|}
\hline Homocysteine & $\begin{array}{l}\text { HIV- } \\
\text { neg }\end{array}$ & $\begin{array}{l}\text { HIV- } \\
\text { pos }\end{array}$ & Total & $\chi^{2}$ & $\begin{array}{l}\text { P } \\
\text { value }\end{array}$ \\
\hline$>18 \mu \mathrm{mol} / \mathrm{L}$ & 65 & 71 & 136 & 1.3 & 0.1 \\
\hline$<18 \mu \mathrm{mol} / \mathrm{L}$ & 61 & 49 & 110 & & \\
\hline Total & 126 & 120 & & & \\
\hline
\end{tabular}

Table 6: Association between age, use of hormone contraceptive, cigarette smoking, duration of illness and homocysteine levels in the HIV positive group

\begin{tabular}{|c|c|c|c|}
\hline Variables & $n(\%)$ & $\begin{array}{c}\text { Mean } \\
\text { levels(sd) }\end{array}$ & $P$ value \\
\hline Sex & & & \multirow{3}{*}{0.5} \\
\hline Male & $67(55.8)$ & $23.3(13.8)$ & \\
\hline Female & $53(44.2)$ & $25.6(14.2)$ & \\
\hline $\begin{array}{c}\text { Use of } \\
\text { hormonal } \\
\text { contracepti } \\
\text { ves }\end{array}$ & & & \multirow[t]{3}{*}{0.2} \\
\hline Yes & $1(0.8)$ & 14.4 & \\
\hline No & $119(99.2)$ & $24.6(14.2)$ & \\
\hline $\begin{array}{c}\text { History of } \\
\text { smoking } \\
\text { cigarettes } \\
\text { (now or in } \\
\text { past } 20 \\
\text { years) } \\
\end{array}$ & & & \multirow[t]{3}{*}{0.6} \\
\hline Yes & $3(2.5)$ & $30.2(27.7)$ & \\
\hline No & $117(97.5)$ & $24.3(14.6)$ & \\
\hline \multicolumn{4}{|l|}{$\begin{array}{l}\text { Duration of } \\
\text { illness }\end{array}$} \\
\hline $\begin{array}{c}\text { Less than 1- } \\
3 \text { years }\end{array}$ & $87(73)$ & $23(14.9)$ & 0.6 \\
\hline 4-7 years & $33(27)$ & $24(11.8)$ & \\
\hline \multicolumn{4}{|l|}{ Age } \\
\hline$<40$ years & $82(68.4)$ & $22(13)$ & \\
\hline$>40$ years & $38(31.6)$ & $28(14)$ & 0.4 \\
\hline
\end{tabular}

Table 7: Association between homocysteine levels and CD4 cell counts in HIV positive group

\begin{tabular}{|l|l|l|l|l|}
\hline & $>18 \mu \mathrm{mol} / 1$ & $<18 \mu \mathrm{mol} / 1$ & $\mathrm{R}$ & $\mathrm{P}$ \\
\hline $\begin{array}{l}\text { CD4 cell } \\
\text { count } \\
\text { Mean } \\
(\mathrm{sd})\end{array}$ & $453(234)$ & $439.1(219)$ & -0.01 & 0.9 \\
\hline
\end{tabular}

Table 5: Hyperhomocysteinemia in the HIV positive on highly active antiretroviral therapy

\begin{tabular}{|l|l|l|l|l|l|l|l|l|}
\hline & \multicolumn{3}{|l|}{ Homocysteine } & & & & & \\
\hline & $\begin{array}{l}>18 \\
\mu \mathrm{mol} / \mathrm{l}\end{array}$ & $\begin{array}{l}<\mathrm{mol} / \mathrm{l} \\
\mu \mathrm{m}\end{array}$ & Tota & $\chi^{2}$ & $\mathrm{p}$-va & Mean $(\mathrm{sc}$ & $\begin{array}{l}\mathrm{p}- \\
\text { valu }\end{array}$ & \\
\hline $\begin{array}{l}\text { HAART- } \\
\text { naïve }\end{array}$ & 27 & 31 & 58 & 7.3 & 0.07 & $22.5(15.5$ & 0.00 & \\
\hline HAART & 44 & 18 & 62 & & & $26.4(12.8$ & & \\
\hline Total & 71 & 49 & & & & & & \\
\hline
\end{tabular}


Female respondents Male respondents

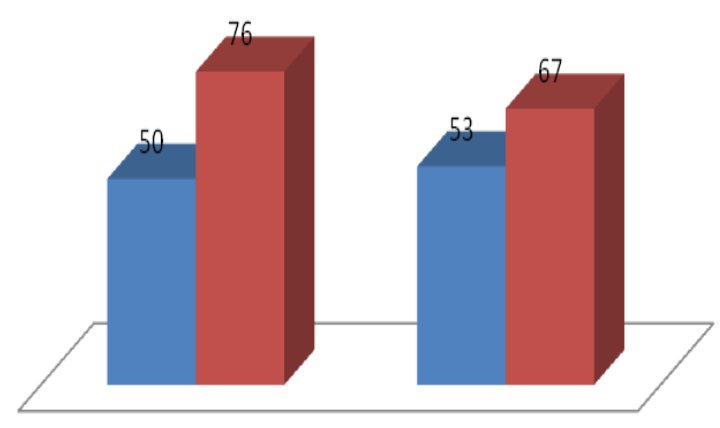

HIVseronegative

HIVseropositive

Fig 1: The number of male and female respondents in both HIV positive and HIV negative group

\section{Discussion:}

Hypercoagulabilty has been reported in several studies of HIV/AIDS patients since the year 2000.(14) These include studies by Kiser et al (15) and Jong et al (16) both in 2010 and Musselwhite et al (17) in 2011. They carried out studies conducted to identify factors responsible for the hypercoagulable state and homocysteine is a major finding in many of these studies. We studied homocysteine in our population of HIV positives and looked for risk factors as a step in identifying risk factors in our patient population. Plasma homocysteine levels were significantly higher in the HIV seropositive population than seronegative controls in this study; $24.4 \mu \mathrm{mol} / \mathrm{L}$ (13.8) vs $19.5 \mu \mathrm{mol} / \mathrm{L}$ (10.6). The prevalence of hyperhomocysteinemia amongst our HIV population is $59.1 \%$. This was similar to a study done by Abdollahi and Shoar in 2012 who assayed homocysteine in HIV living in Iran(18). They reported a prevalence of $91 \%$ hyperhomocysteinaemia in a cohort of 58 HIV positive Iranian individuals. They postulated that hyperhomocysteinemia in the HIV positive group was as a result of the effects of HIV replication on host metabolism. In their study, higher homocysteine levels found were associated with older individuals. This study did not however, find any association between age and plasma homocysteine levels. It is important to note, however, that the mean age of his respondents was higher in that study compared with the ages in this study and this could account for the differences found. CD4+ $\mathrm{T}$ cell counts are the laboratory parameters used widely to classify and stage HIV/AIDS by the CDC (19). In the current study, there was no statistical correlation between the CD4+ $\mathrm{T}$ cell count and homocysteine. But we found that the CD 4 cell count among the patient with hyperhomocysteinemia was only slightly higher than that found with normal homocysteine levels. Abdollahi and Shoar (18) could not find any association between CD 4 cell counts and homocysteine levels either. They surmised that the stage of HIV infection does not appear to be correlated with the plasma homocysteine level. This can have potential implications for intervention.

Farbod et al in 2010 (20), another investigator of homocysteine in HIV infected patients, on the other hand, did not find any significant difference in the plasma homocysteine levels in a cohort of 249 women infected with HIV at the Bronx Women's Interagency HIV study site in the USA when he compared them with HIV negative controls. That study instead reported strong positive associations between older ages, a lower $\mathrm{CD} 4+\mathrm{T}$ cell and higher plasma homocysteine levels irrespective of their HIV status. We found instead the mirror opposite in our study. The Bronx study differed from our study in that their entire population was made up of targeted groupmiddle aged females while this study was carried out amongst the young adults of both sexes. The CD4+ $\mathrm{T}$ cell counts in both studies were comparable. the patient populations of our study and the Bronx study have completely different population characteristics which accounts for the different outcome. Demince et al (22) performed a meta-analysis on 16 studies and found that the HIV group that were on HAART had a higher mean homocysteine level than the HIV HAART naïve group. they noted that the difference in plasma homocysteine levels between patients on anti-retroviral and those that were HAART naive was $4.13 \mu \mathrm{mol} / 1$. In our study, the patients on HAART had a higher homocysteine level compared with the HAART naive. This may be explained by the presence of patients who are on protease inhibitors which have been known to cause elevation in homocysteine levels. We found no significant association between homocysteine and traditional risk factors for hyperhomocysteinemia (age, smoking of 
cigarettes, use of oral contraceptives) but this was in keeping with knowledge on homocysteine levels in HIV. HIV is an inflammatory condition, characterized by the perturbation of many metabolic pathways in the body. Thus traditional risk factors will exert may have less influence on pathogenesis of hyperhomocysteinemia in that particular population.

\section{Conclusion:}

Plasma homocysteine level is high amongst the HIV seropositive cohort and the majority of them had hyperhomocysteinemia.

\section{References}

1. Codoñer-Franch P., Alonso-Iglesias E. (2016) Homocysteine as a Biomarker in Vascular Disease. In: Patel V., Preedy V. (eds) Biomarkers in Cardiovascular Disease. Biomarkers in Disease: Methods, Discoveries and Applications. Springer, Dordrecht

2. Kumar A, Palfrey HA, Pathak R, Kadowitz PJ, Gettys TW, Murthy SN. The metabolism and significance of homocysteine in nutrition and health. Nutr Metab (Lond). 2017;14:78.. doi:10.1186/s12986-017-0233-z

3. Jakubowski H (2007) The molecular basis of homocysteine thiolactone-mediated vascular disease. Clin Chem Lab Med 45:1704-1716

4. Coria-Ramirez E, Cisneros LN, TrevinoPerez S, Ibarra-Gonzalez I, CasillasRodriguez J, Majluf-Cruz A. Effect of highly active antiretroviral therapy on homocysteine plasma concentrations in HIV-1-infected patients. J Acquir Immune Defic Syndr. 2010; 54(5):477-4781.

5. Olszewski AJ, McCully KS. Homocysteine metabolism and the oxidative modification of proteins and lipids. Free Radic Biol Med. 1993;14(6):683-693.

6. Eberhardt RT, Forgione MA, Cap A, Leopold JA, Rudd MA, Trolliet M, et al. Endothelial dysfunction in a murine model of mild hyperhomocyst (e) inemia. J Clin Invest. 2000;106(4):483-491.

7. Undas A, Williams EB, Butenas S, Orfeo T, Mann KG. Homocysteine inhibits inactivation of factor $\mathrm{Va}$ by activated protein C. J Biol Chem. 2001; 276(6):4389-4397.

8. Rodgers GM, Kane WH. Activation of endogenous factor $\mathrm{V}$ by a homocysteineinduced vascular endothelial cell activator. J Clin Invest. 1986;77(6):1909-1916.

9. Jakubowski H. Protein homocysteinylation: Possible mechanism underlying pathological consequences of elevated homocysteine levels. FASEB J. 1999;13(15):2277-2283.

10. Collet JP, Soria J, Mirshahi M, Hirsch M, Dagonnet FB, Caen J, et al. Dusart syndrome: a new concept of the relationship between fibrin clot architecture and fibrin clot degradability: hypofibrinolysis related to an abnormal clot structure. Blood. 1993; 82(8):24622469.

11. Sauls DL, Wolberg AS, Hoffman M. Elevated plasma homocysteine leads to alterations in fibrin clot structure and stability: implications for the mechanism of thrombosis in hyperhomocysteinemia. $\mathbf{J}$ Thromb Haemost. 2003;1(2):300-306.

12. Duro M , Manso MC, Rebelo I, Medeiros $\mathrm{R}$, Almeida $\mathrm{C}^{*}$ Hyperhomocysteinemia in human immunodeficiency virus-infected patients. Biomedical Research .2016. Volume 27, Issue 2:557-562

13. Bongiovanni M; Casana M; Tordato F; Cicconi P; Ranier P; Monforte A, Bini T; Pisacreta M; Russo U. Predictive Factors of Hyperhomocysteinemia in HIV-Positive Patients. JAIDS Journal of Acquired Immune Deficiency Syndromes. 2007; 44( 1): 117-119

14. Summer LM, Marso SP, Grant PJ. Atherothrombosis,thrombolysis and antiplatelet. In: Hoffbrand AV, Catovsky, Tuddenham EG, editors. Postgraduate Haematology.5th ed. New-Delhi: Wiley; 2005: 945-965

15. Kiser KL, Badowski ME. Risk factors for venous thromboembolism in patients with 
human immunodeficiency virus infection. Pharmacotherapy. 2010;30(12):1292-1302.

16. Jong E, Louw S, Van Gorp E, Meijers J, TenCate H, Jacobson B. The effect of initiating combined antiretroviral therapy on endothelial cell activation and coagulation markers in South African HIV-infected individuals. Thromb Haemost. 2010; 104(6): 1228-1234.

17. Musselwhite LW, Sheikh V, Norton TD, Rupert A, Porter BO, Penzak SR, et al. Markers of endothelial dysfunction, coagulation and tissue fibrosis independently predict venous thromboembolism in HIV. AIDS. 2011; 25(6):787-795

18. Abdollahi A, Shoar TS. Hyperhomocysteinemia in HIV-Infected Individuals: Correlation of a Frequent Prothrombotic Factor with CD4+ Cell Count. Oman Medical Journal. 2012;27(3):224-227. doi:10.5001/omj.2012.50.

19. Center for Disease Control.1993 revised classification system for HIV infection and expanded surveillance case definition for AIDS among adolescents and adults. MMWR Recomm Rep.1992; 41:1-19.

20. Farbod R, Donald RH, Irene L, Qiuhu S, Anastos A, Wei G, Kaplan R, et al. Brief Report: Plasma Homocysteine is Not Associated with HIV Serostatus or Antiretroviral Therapy in Women. J Acquir Immune Defic Syndr. 2010; 51(2): 175-178

21. Michele GB, Andrea A. HIV-Associated Venous Thromboembolism. Mediterr J Haematol Infect Dis. 2011;3(1):1-26.

22. Deminice R, Silva TC, De Oliveira VH. Elevated homocysteine levels in human immunodeficiency virus-infected patients under antiretroviral therapy: A metaanalysis. World Journal of Virology, 2015. $4(2), 147-155$. http://doi.org/10.5501/wjv.v4.i2.147 